\title{
SH3 Domain-Containing Kinase-Binding Protein 1
}

National Cancer Institute

\section{Source}

National Cancer Institute. SH3 Domain-Containing Kinase-Binding Protein 1. NCI

Thesaurus. Code C132143.

SH3 domain-containing kinase-binding protein 1 (665 aa, $73 \mathrm{kDa}$ ) is encoded by the human SH3KBP1 gene. This protein is involved in the modulation of protein-protein interactions. 